\title{
A Novel Penicillium sp. Causes Rot in Stored Sugar Beet Roots in Idaho
}

\author{
Carl A. Strausbaugh, ${ }^{\dagger}$ USDA-ARS, NWISRL, Kimberly, ID 83341; and Frank Dugan, USDA-ARS, Western Regional Plant Introduction
} Station, Washington State University, Pullman 99164-6402

\begin{abstract}
Penicillium vulpinum along with a number of other fungi can lead to rot of stored sugar beet roots. However, Penicillium isolates associated with necrotic lesions on roots from a recent sugar beet storage study were determined to be different from $P$. vulpinum and other recognized Penicillium species. Phylogenies based on sequencing of the internal transcribed spacer (ITS)-5.8S, $\beta$-tubulin (BenA), and RNA polymerase II second largest subunit (RPB2) DNA regions indicate that these isolates are novel, but most closely related to the following Penicillium spp. in the section Fasiculata:

$P$. aurantiogriseum, $P$. camemberti, and $P$. freii. Macro- and micromorphological data also support designating these isolates as a new species for which we propose the name, Penicillium cellarum sp. nov. Inoculation studies with the $P$. cellarum isolates on roots of the commercial sugar beet cultivar B-7 led to the formation of necrotic lesions 23 to $25 \mathrm{~mm}$ in diameter after 86 days in storage. These lesions were similar to those observed on sugar beet roots in commercial storage piles. These data indicate that $P$. cellarum is a pathogen which can cause root rot in stored sugar beet roots.
\end{abstract}

Sugar beet (Beta vulgaris L.) roots are frequently stored under ambient conditions in the United States in production areas other than the Red River Valley and California (Bugbee 1993). In Idaho, which is second in sugar beet production (USDA-NASS) in the United States, approximately two-thirds of the crop is held under ambient storage conditions from October until late March when factory processing is finished (Huff 2013; Peterson et al. 1984; Strausbaugh et al. 2008). At harvest, roots are topped and handled roughly when loaded into trucks and piles, making them susceptible to injury and increased respiration and microbial invasion (Bugbee 1993; Wyse and Peterson 1979). If weather conditions are unfavorable, such as widely fluctuating temperatures and wet conditions, microbial growth can be enhanced (Bugbee 1982, 1993; Strausbaugh et al. 2008, 2011; Wyse 1978). Bacterial rot has been documented to be caused by Leuconostoc, while fungal invasion can be attributed to a number of causal agents including an Athelia-like basidiomycete, Botrytis cinerea Pers., Penicillium vulpinum (Cooke \& Massee) Seifert \& Samson (syn. P. claviformae Bainer), and Phoma betae A. B. Frank (Bugbee 1982; Bugbee and Cole 1976; Campbell and Bugbee 1993; Liebe and Varrelmann 2014; Miles et al. 1977; Mumford and Wyse 1976; Nihlgård et al. 2009; Strausbaugh et al. 2009, 2015; Toda et al. 2012).

Penicillium storage rot is normally associated with wounds and historically attributed to $P$. vulpinum (Bugbee 1975, 1976, 1993; Fugate and Campbell 2009). However, other Penicillium spp. [P. cyclopium Westling (syn. P. bordzilowskii Morotchkovsky), P. duclauxii Delacr., $P$. expansum Link, $P$. paneum Frisvad, $P$. rubrum Stoll, and $P$. stoloniferum Thom] and two former members of this genus [Talaromyces funiculosus (Thom) Samson, Yilmaz, Frisvad, \& Seifert (syn. P. funiculosum Thom) and Talaromyces variabilis (Sopp) Samson, Yilmaz, Frisvad, \& Seifert (syn. P. variabile Sopp)] have also been identified as sugar beet storage pathogens (Bugbee 1975; Bugbee and Nielsen 1978; Fugate and Campbell 2009; Liebe et al. 2016; Morotchkovsky 1936, Samson et al. 2011; Visagie et al. 2014). Penicillium roqueforti Thom and $P$. paneum have also been isolated from

${ }^{\dagger}$ Corresponding author. E-mail: carl.strausbaugh@ars.usda.gov

Mention of trade names or commercial products in this article is solely for the purpose of providing scientific information and does not imply recommendation or endorsement by the U.S. Department of Agriculture.

Accepted for publication 8 June 2017.

This article is in the public domain and not copyrightable. It may be freely reprinted with customary crediting of the source. The American Phytopathological Society, 2017. ensiled hard-pressed beet fibers (Boysen et al. 2000). Recently Penicillium isolates from lesions on sugar beet roots in Idaho differed from previously acknowledged species based on phylogenetic analysis (Strausbaugh et al. 2015). This novel pathogenic Penicillium species was established using a polyphasic taxonomic approach suggested by Visagie et al. (2014) via molecular data [partial sequences for internal transcribed spacer-5.8S ribosomal DNA (ITS), $\beta$-tubulin (BenA), and RNA polymerase II second largest subunit (RPB2)] and macro- and micromorphological characteristics.

\section{Materials and Methods}

Sample collection and isolation. Four Penicillium isolates (F727, F728, F730, and F732) were collected on 8 February 2013 from necrotic lesions on commercial sugar beet roots that were part of a previous storage study (Strausbaugh et al. 2015). The isolation methods were described previously (Strausbaugh et al. 2015). The isolates were single spored and stored on sterile barley kernels at $-80^{\circ} \mathrm{C}$ using the following method. The barley kernels had been soaked in tap water for $24 \mathrm{~h}$, and then autoclaved twice for $1 \mathrm{~h}$ at $121^{\circ} \mathrm{C}$ on consecutive days. Plugs from potato dextrose agar (PDA; Becton Dickinson $\&$ Co., Sparks, MD) cultures were placed with the barley kernels and incubated at $21^{\circ} \mathrm{C}$ for six weeks. The kernels were then placed in cryovials and stored at $-80^{\circ} \mathrm{C}$ until retrieved for this study.

Macromorphology. Macromorphological characters were established on Czapek yeast autolysate agar (CYA), malt extract agar (MEA), yeast extract sucrose agar (YES), and creatine sucrose agar (CREA) prepared in 90-mm polystyrene Petri dishes with a volume of $20 \mathrm{ml}$ as described by Frisvad and Samson (2004). Three plates of each isolate were inoculated with a spore suspension in semisolid agar solution containing $0.2 \%$ agar. All media were incubated in the dark at the standard temperature of $25^{\circ} \mathrm{C}$ for $7 \mathrm{~d}$. Additional CYA plates were incubated at 30 and $37^{\circ} \mathrm{C}$. After $7 \mathrm{~d}$, the colony diameters were measured at the widest part of the colony. The colony texture, degree of sporulation, conidial color, texture and color of mycelia, the presence and color of soluble pigments and exudates, reverse colony color, colony diameter, and acid/base production were documented as described by Frisvad and Samson (2004).

Micromorphology. Micromorphology characters such as the number of branching points between stipe and phialides; and the dimension, shape, and texture of stipes, rami, metulae, phialides, and conidia were investigated. These characters were established on microscopic slides prepared from 7- to 10-d-old MEA cultures. Measurements were made at 400 to $1000 \times$ on a $\mathrm{BH} 2$ Olympus microscope (Olympus Optical Co, LTD, Japan) and features recorded with a D5000 Nikon digital camera (Nikon Corp., Tokyo, Japan). Measurement comparisons for conidia $(n=50)$, phialides $(n=20)$, metulae $(n=20)$, and rami $(n=20)$ were conducted with Systat 13.10 (Systat 
Software, Inc., Chicago, IL), with GLM pair-wise comparisons grouped by treatment using post hoc test of Fisher's least significant difference (LSD). The error terms were mean square error (MSE).

Growth at different temperatures. The fungal strains were freshly revived from glycerol stocks to 1/2-strength V8 agar and grown at room temperature under 12-h diurnal combined near-UV/cool white lighting for one week. Conidial suspensions created by subculture from sporulating 1/2-strength V8-agar plates were prepared in $0.2 \%$ semiliquid agar vials which were employed to create a single point of inoculum at the center of each CYA plate (Pitt 2000). Each strain was inoculated in triplicate to CYA at each of four temperatures: 5, 8, 21, and $30^{\circ} \mathrm{C}$. The inoculated CYA plates to be incubated at a specific temperature were randomly stacked and wrapped in foil for incubation in the dark. HOBO data loggers were used to monitor temperature uniformity. The maximum colony diameter was recorded from each plate under $5 \times$ magnification approximately every $48 \mathrm{~h}$ for 12 days. Data were analyzed in TableCurve 2D for Windows (Version 4.07; SPSS Inc.,

Table 1. GenBank accessions used in the phylogenetic analyses to compare DNA regions of Penicillium spp.

\begin{tabular}{|c|c|c|c|c|}
\hline \multirow[b]{2}{*}{ Species } & \multirow[b]{2}{*}{ Strain $^{y}$} & \multicolumn{3}{|c|}{ GenBank accessions $^{\mathbf{z}}$} \\
\hline & & ITS & BenA & RPB2 \\
\hline cellarum sp. nov. & F727 & KM249068 & KM249108 & KM249117 \\
\hline cellarum sp. nov. & F728 & $\begin{array}{c}\text { Same as } \\
\text { F727 }\end{array}$ & $\begin{array}{c}\text { Same as } \\
\text { F727 }\end{array}$ & $\begin{array}{c}\text { Same as } \\
\text { F727 }\end{array}$ \\
\hline cellarum sp. nov. & F730 & KM249070 & $\begin{array}{c}\text { Same as } \\
\text { F727 }\end{array}$ & $\begin{array}{c}\text { Same as } \\
\text { F727 }\end{array}$ \\
\hline cellarum sp. nov. & F732 & KM249072 & $\begin{array}{l}\text { Same } \\
\quad \text { as F727 }\end{array}$ & $\begin{array}{c}\text { Same as } \\
\text { F727 }\end{array}$ \\
\hline albocoremium & CBS472.84 & AJ004819 & AY674326 & None \\
\hline allii & CBS131.89 & AJ005484 & AY674331 & None \\
\hline aurantiogriseum & CBS249.89 & AF033476 & AY674296 & JN406573 \\
\hline biforme & CBS297.48 & KC411731 & FJ930944 & None \\
\hline camemberti & CBS299.48 & AB479314 & FJ930956 & JN121484 \\
\hline caseifulvum & CBS101134 & KJ834504 & AY674372 & None \\
\hline cavernicola & CBS100540 & KJ834505 & KJ834439 & None \\
\hline commune & CBS311.48 & AY213672 & AY674366 & None \\
\hline crustosum & CBS115503 & AF033472 & AY674353 & None \\
\hline cyclopium & CBS114.45 & JN097811 & AY674310 & JN985388 \\
\hline discolor & CBS474.84 & AJ004816 & AY674348 & None \\
\hline echinulatum & CBS317.48 & AF033473 & AY674341 & None \\
\hline expansum & CBS325.48 & AY373912 & AY674400 & $\mathrm{JF} 417427$ \\
\hline freii & CBS476.84 & JN942696 & AY674290 & JN985430 \\
\hline hirsutum & CBS135.41 & AY373918 & AF003243 & JN406629 \\
\hline hordei & CBS701.68 & None & AY674347 & None \\
\hline melanoconidium & CBS115506 & AJ005483 & AY674304 & None \\
\hline neoechinulatum & CBS169.87 & JN942722 & AF003237 & JN985406 \\
\hline nordicum & ATCC44219 & KJ834513 & KJ834476 & None \\
\hline osmophilum & CBS462.72 & EU427295 & AY674376 & JN121518 \\
\hline palitans & CBS107.11 & KJ834514 & KJ834480 & None \\
\hline polonicum & CBS222.28 & AF033475 & AY674305 & JN406609 \\
\hline radicicola & CBS112430 & KJ834516 & AY674357 & None \\
\hline solitum & CBS424.89 & AY373932 & AY674354 & None \\
\hline thymicola & CBS111225 & KJ834518 & AY674321 & None \\
\hline tricolor & CBS635.93 & JN942704 & AY674313 & JN985422 \\
\hline tulipae & CBS109555 & KJ834519 & AY674344 & None \\
\hline venetum & IBT10661 & AJ005485 & AY674335 & None \\
\hline verrucosum & CBS603.74 & AY373938 & AY674323 & JN121539 \\
\hline viridicatum & CBS390.48 & AY373939 & AY674295 & JN121511 \\
\hline
\end{tabular}

${ }^{\mathrm{y}}$ The Penicillium cellarum type strain F727 has been deposited as WSP 72897 holotype and NRRL 66633 ex-type. The strain F728 was deposited as WSP 72898 and NRRL 66634. Strains F730 and F732 were deposited as WSP 72899 and WSP 72900, respectively.

${ }^{\mathrm{z}}$ GenBank accessions representing the following DNA regions: ITS $=$ internal transcribed spacer-5.8S rDNA region; BenA $=\beta$-tubulin region; and RPB2 $=$ RNA polymerase II second largest subunit region. None $=$ no sequence available on GenBank. Penicillium species sequences for the type strains from the section Fasiculata were obtained from GenBank. Penicillium expansum was included as the outgroup in the phylogenetic analyses and belongs in section Penicillium.
Chicago, IL) to select the model that best fit the individual data points. The model fit was confirmed using SAS (Version 9.4, SAS Institute Inc., Cary, NC) with Proc reg.

Molecular characterization. The following DNA regions were sequenced: ITS, BenA, and RPB2. The isolates were each grown in potato dextrose broth (PDB; Becton Dickinson \& Co.), freeze-dried, and pulverized using methods described previously (Strausbaugh et al. 2015). DNA was extracted using a DNeasy Plant Mini Isolation Kit (Qiagen Inc., Valencia, CA) following standard protocols suggested by the manufacturer and stored at $-20^{\circ} \mathrm{C}$. Polymerase chain reaction (PCR) assays were performed in volumes of $30 \mu \mathrm{l}$ using GoTaq Taq DNA polymerase (Promega Corp., Madison, WI) with primers and methods described previously (Strausbaugh et al. 2015). Amplification products were electrophoresed through agarose gels $(1.8 \% \mathrm{w} / \mathrm{vol})$ supplemented with ethidium bromide $(0.01 \mathrm{mg} / \mathrm{ml})$ in Tris borate EDTA buffer (TBE, $89 \mathrm{mM}$ Tris base, $89 \mathrm{mM}$ boric acid, and $2 \mathrm{mM}$ EDTA). Amplicons were sequenced in both directions by TACGen (Richmond, CA). Sequences were evaluated using BioEdit 7.1.3.0 (Hall 1999), consensus sequences were generated, and representative haplotypes were submitted to GenBank (Accession Nos. KM249066 to KM249138; Table 1).

The sequences for isolates F727, F728, F730, and F732 were compared with accessions in GenBank using BLASTn 2.2.28 (Altschul et al. 1997), which determined that the most closely related species were Penicillium spp. in the section Fasciculata. Type strain sequences (Table 1) for the species in this section (specified in Visagie et al. 2014) were compared with the sugar beet isolates via phylogenetic analysis. Penicillium expansum was included as the outgroup in the phylogenetic analyses and belongs in section Penicillium. DNA sequences were aligned using ClustalX Ver. 2.0 (Larkin et al. 2007). The maximum parsimony analysis was performed using PAUP with the heuristic search, simple taxon addition sequences, tree bisectionreconnection $($ TBR) branch swapping, and MaxTrees $=100$. Statistical support for the analyses was determined by bootstrap values for 1,000 replicates. MEGA 6.05 (Tamura et al. 2011) was used to determine the substitution model that best fit the data according to the Bayesian information criterion (BIC). The substitution models selected were as follows: T92 (Tamura 3-parameter model) for ITS; $\mathrm{K} 2+\mathrm{G}$ (Kimura 2-parameter model with gamma distribution) for $\mathrm{RPB} 2$; and $\mathrm{K} 2+\mathrm{I}$ (Kimura 2-parameter model with invariant sites) for BenA. Maximum likelihood analyses were conducted with MEGA with an initial search (two replicates) used to estimate the model parameters. The parameters were then fixed for a bootstrap analysis of 1,000 replicates. The Bayesian phylogenetic analyses were conducted with MrBayes 3.2.1 (Ronquist and Huelsenbeck 2003) with the searches run until the standard deviation of split frequencies fell $<0.01$. The analyses were conducted using the default priors. The majority-rule consensus was then calculated after removing the first $25 \%$ of generations as burn-in. The trees were visualized using FigTree Ver. 1.4 (Inst. of Evol. Biol., Univ. of Edinburgh UK).

Rot tests. To investigate the rot potential of the sugar beet Penicillium isolates, the isolates were inoculated into stored sugar beet roots. Roots of the commercial sugar beet cultivar B-7 (for the uncoded cultivar name contact Betaseed Inc., Kimberly, ID) were grown on the USDA-ARS North Farm $\left(42^{\circ} 33^{\prime} 10.60^{\prime \prime}\right.$ N, 114 ${ }^{\circ} 21^{\prime} 27.27^{\prime \prime}$ W, elev. $1,187 \mathrm{~m}$ ) near Kimberly, ID, using standard cultural practices outlined in the 2016 Amalgamated Sugar Co. (Boise, ID) grower guidebook. The roots were mechanically harvested on 11 October 2016 and placed in wooden onion boxes $(4 \mathrm{ft} \times 6 \mathrm{ft} \times 30$ inches; Boise River Pack, Notus, ID) inside a commercial sugar beet storage building (temperature set point $1.1^{\circ} \mathrm{C}$, relative humidity remained above 90\%; cooled using ambient air) in Paul, ID. During storage, the temperature in the storage building was recorded at 1-h intervals using HOBO sensors (Model H08-001-02; Onset Computer Corp., Bourne, MA). The experiment was arranged on the bottom of an onion box in a randomized complete block design with six replications per treatment (a single root was the experimental unit). There were five treatments: a PDA check and four Penicillium isolates (F727, F728, F730, and F732) inoculated individually. A cork borer plug (10 mm diameter by $24 \mathrm{~mm}$ deep) was pulled from the shoulder of the root on 9 November to allow for inoculation. For the PDA check, an 
$8 \mathrm{~mm}$-diameter PDA plug was placed in the hole. For the Penicillium treatments, an 8-mm-diameter plug from a 2-week-old culture grown on PDA at $22^{\circ} \mathrm{C}$ was placed in the hole. The root plug was replaced after inoculation and sealed with petroleum jelly (UNILIVER, Greenwich, CT). After 86 days in storage on 3 February 2017, the diameter of the discolored tissue was measured. Reisolations (three reisolations per treatment) were conducted by transfer of tissue from the leading edge of the discolored tissue in the Penicillium inoculated roots and from the noninoculated checks onto PDA amended with streptomycin (200 mg/liter). The reisolations were conducted using methods described previously (Strausbaugh et al. 2015). The experiment was repeated beginning on 15 November using the same source of roots, conditions, and length of time in storage as the first experiment. The SAS univariate procedure was used to test for normality of the data. The homogeneity of variance was investigated using Levene's test (HOVTEST = Levene). Analysis of variance was conducted using SAS general linear models procedure (Proc
GLM). Mean comparisons were conducted using Fisher's protected least significant difference with $\alpha=0.05$.

\section{Results}

Species placement and characterization. Based on macro- and micromorphological characteristics and phylogenetic analyses, the Penicillium sp. isolated from necrotic tissue in sugar beet roots held in an indoor storage building in Paul, ID, was a new species, for which we propose the name Penicillium cellarum.

Penicillium cellarum Strausbaugh and Dugan, sp. nov.

Mycobank: MB 820525

Etymology: Named after the Latin word cellarum, which means "of stores"

Deposits: Isolate F727 has been deposited as WSP 72897 holotype and NRRL 66633 ex-type. Isolate F728 was deposited as WSP 72898 and NRRL 66634. Isolates F730 and F732 were deposited as WSP 72899 and WSP 72900, respectively.
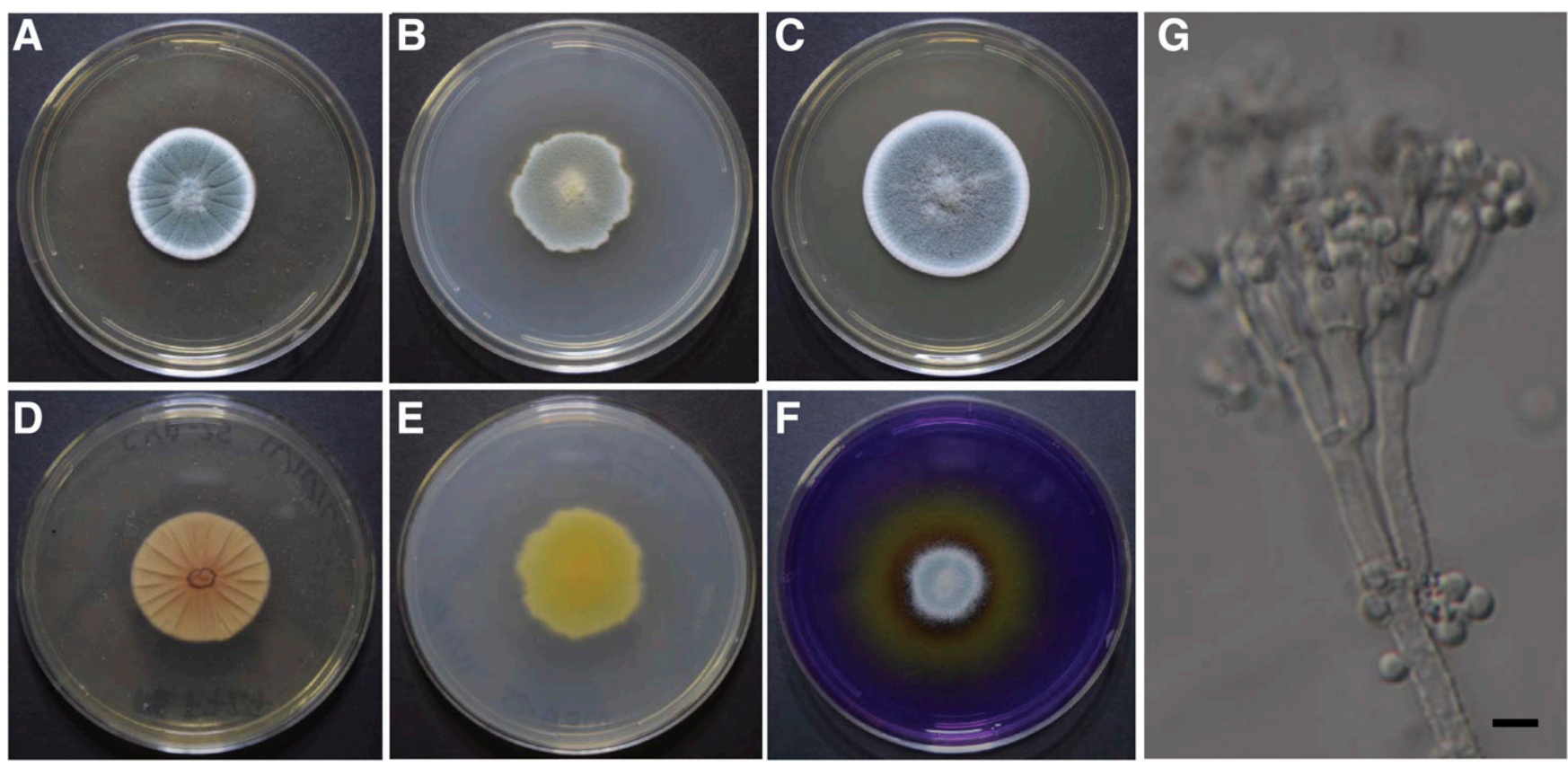

Fig. 1. Growth of Penicillium cellarum sp. nov., isolate $\mathrm{F} 727$ (holotype) at $25^{\circ} \mathrm{C}$ after 7 days on A, Czapek yeast autolysate agar (CYA), B, malt extract agar (MEA), C, yeast extract sucrose agar, D, CYA reverse, E, MEA reverse, and F, Creatine sucrose agar. Yellow hallow indicates moderate acid production. Penicillus $(\mathbf{G})$, bar $=5 \mu \mathrm{m}$.
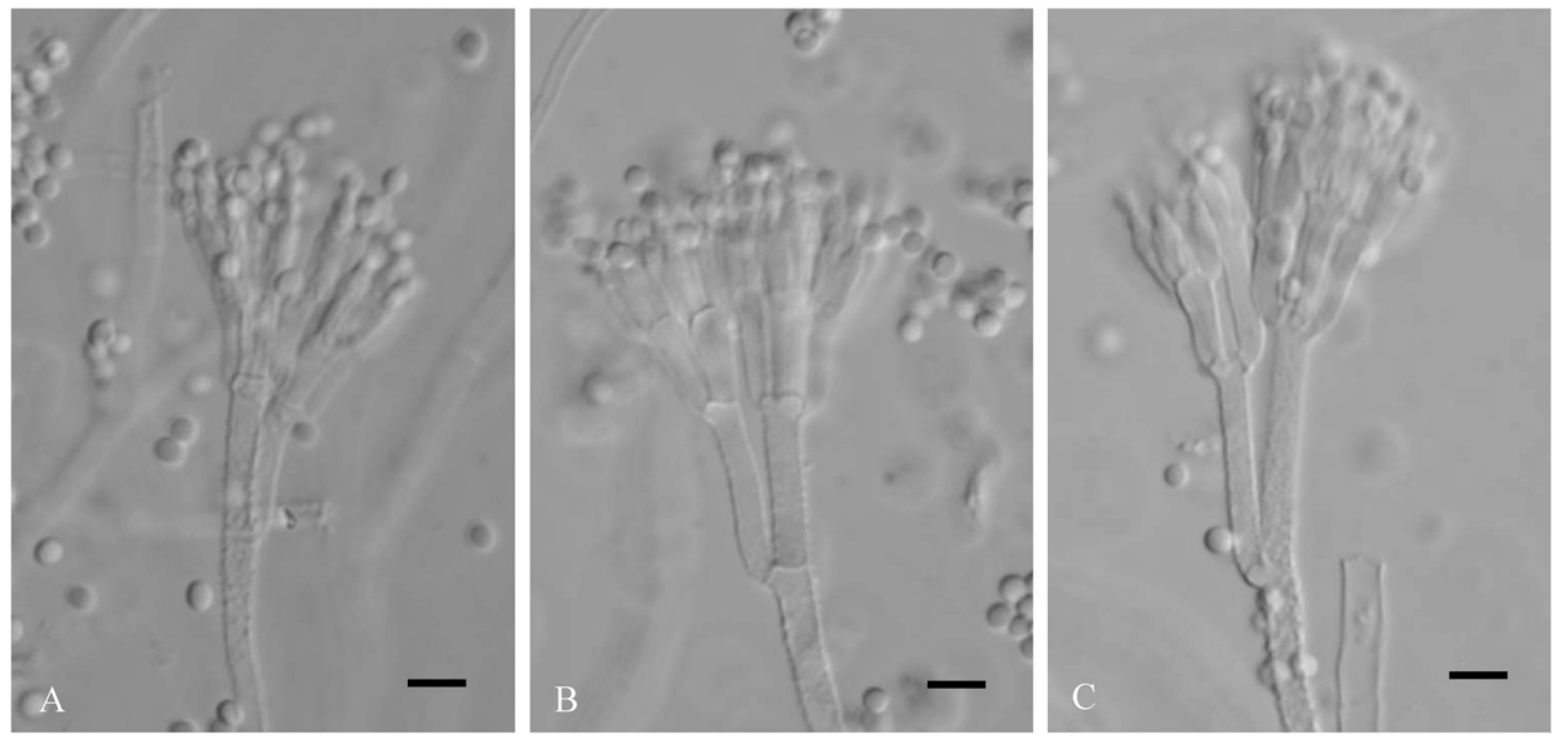

Fig. 2. Terverticillate pencilli of $P$. cellarum sp. nov. for isolates A, F728, B, F730, and C, F732, bars $=5 \mu \mathrm{m}$. 
Macromorphology. On CYA after $7 \mathrm{~d}$ at $25^{\circ} \mathrm{C}$, the colonies were 27 to $44($ mean $=32) \mathrm{mm}$ in diameter, were dull blue-green, velutinous, with white margin, sulcate, with minute amounts of colorlesspale tan exudate, and the reverse was cream-beige to very light brown (Fig. 1). On CYA after $7 \mathrm{~d}$ at $30^{\circ} \mathrm{C}$, the colonies were 9 to 21 (mean $=$ 13) $\mathrm{mm}$ in diameter, were dull blue-green, velutinous, sulcate to convoluted with a sinuate white margin, and in reverse red-brown and usually with a red-brown soluble pigment. On CYA after $7 \mathrm{~d}$ at $37^{\circ} \mathrm{C}$, there was no growth. On MEA after $7 \mathrm{~d}$ at $25^{\circ} \mathrm{C}$, the colonies 32 to $54($ mean $=39) \mathrm{mm}$ in diameter, were dull blue-green, velutinous, and with a slightly off-white margin and in reverse pale, dull yellowish gray-green with traces of a pale yellow diffusible pigment. On CREA after $7 \mathrm{~d}$ at $25^{\circ} \mathrm{C}$, the colonies were 31 to $39($ mean $=34)$ $\mathrm{mm}$ in diameter, and acid production was moderate (halo of yellow pigment around colony $=+$ ). After 10 to 14 days on CREA at $25^{\circ} \mathrm{C}$, there was base production (purple reverse $=+$ ) with some isolates. On YES after $7 \mathrm{~d}$ at $25^{\circ} \mathrm{C}$, the colonies were 39 to 54 (mean $=43$ ) $\mathrm{mm}$ in diameter, dull blue-green, velvety to slightly granular, white margin finely sulcate, and in reverse a dull yellowish gray-cream.

Micromorphology on MEA. Conidiophores were typically single (Figs. 1 and 2). Stipes were hyaline, roughened (verruculose), (80-) 85-450 × (3.1-) 4.0-4.2(-4.4) $\mu \mathrm{m}$, bearing terminal terverticillate (occasionally biverticillate, rarely quaterverticillate) penicillii. Rami were typically two (sometimes three) per stipe, usually appressed or only narrowly divergent, hyaline, roughened, and averaged $20.4 \pm$ $3.8 \times 3.7 \pm 0.4 \mu \mathrm{m}$ (Table 2 ). Metulae were typically 4 to 5 per ramus, appressed to narrowly divergent, hyaline, smooth, and averaged $11.3 \pm$ $1.7 \times 3.4 \pm 0.4 \mu \mathrm{m}$. Phialides were typically 6 to 8 per metula, hyaline, smooth, ampulliform, slender, and averaged $8.6 \pm 1.0 \times 2.7 \pm 0.2 \mu \mathrm{m}$ (including collula). Conidia were typically smooth, globose to sometimes subglobose, rarely elliptical, pale green in bright field, and averaged $2.9 \pm 0.2 \mu \mathrm{m}$ in diameter, borne in columns. Significant differences $(P \leq 0.03)$ were obtained between isolates with regard to length of metulae (maximum difference $=2.1 \mu \mathrm{m}$, between means for F732 and F728) and width of rami (maximum difference = $0.4 \mu \mathrm{m}$, between means for F730 and F732), indicating some degree of within-species variation (data not shown). There were no significant differences in dimensions of conidia and phialides among the four isolates.

Table 2. Dimensions of conidia, phialides, metulae, and rami for isolates of Penicillium cellarum sp. nov.

\begin{tabular}{|c|c|c|}
\hline Characteristic & Isolate & Dimensions $(\mu \mathbf{m})^{\mathbf{z}}$ \\
\hline \multirow[t]{5}{*}{ Conidia } & F727 & $(2.5-) 2.7-3.4(-3.5)$ \\
\hline & F728 & (2.2-) 2.5-3.4 (-3.9) \\
\hline & F730 & 2.4-3.5 \\
\hline & F732 & $2.5-3.8$ \\
\hline & Overall mean & $2.9 \pm 0.2$ \\
\hline \multirow[t]{5}{*}{ Phialides } & F727 & $(6.3-)$ 7.0-10.1 (-10.9) $\times(2.0-)$ 2.1-2.9 \\
\hline & F728 & $(6.3-) 6.9-11.2(-11.9) \times 2.4-2.9$ \\
\hline & F730 & $(6.7-)$ 7.0-11.2 × 2.2-3.0 \\
\hline & F732 & $7.0-10.5(-11.2) \times 2.1-2.9$ \\
\hline & Overall mean & $8.6 \pm 1.0 \times 2.7 \pm 0.2$ \\
\hline \multirow[t]{5}{*}{ Metulae } & F727 & $(7.0-)$ 8.4-14.1 (-17.2) $\times(2.8-) 3.0-4.2$ \\
\hline & F728 & (7.0-) 8.4-13.8 (-14.0) × 2.8-4.3 \\
\hline & F730 & (7.0-) 9.2-14.1 (-15.4) × 2.7-4.3 \\
\hline & F732 & $(7.0-)$ 8.4-15.4 (-17.5) × 2.9-4.2 \\
\hline & Overall mean & $11.3 \pm 1.7 \times 3.4 \pm 0.4$ \\
\hline \multirow[t]{5}{*}{ Rami } & F727 & $(14.0-) 18.2-25.9(-28.0) \times(2.9-) 3.1-4.5$ \\
\hline & F728 & (14.0-) $15.4-29.4 \times 3.0-4.6$ \\
\hline & F730 & $11.9-32.0(-35.0) \times 3.2-4.6$ \\
\hline & F732 & $14.2-26.6 \times 2.8-4.3$ \\
\hline & Overall mean & $20.4 \pm 3.8 \times 3.7 \pm 0.4$ \\
\hline
\end{tabular}

${ }^{\mathrm{z}}$ Dimensions for conidial diameter $(\mathrm{n}=50)$, phialides $(\mathrm{n}=20$; length $\times$ width $)$, metulae $(n=20$; length $\times$ width), and rami $(n=20$; length $\times$ width). Numbers in parentheses indicate the highest observed values associated with outliers. If there are no parentheses, then the highest observed value fell within the sample. Overall mean $=$ mean of the four isolates along with their mean squared error.
Growth at different temperatures. Averaged over the four isolates, colony diameter was $13.4,23.8,56.8$, and $30.4 \mathrm{~mm}$ at 5, 8, 21, and $30^{\circ} \mathrm{C}$, respectively (Fig. 3). Data were fit to the regression equation $\mathrm{y}=9.22+0.32 \mathrm{X}^{2}-0.01 \mathrm{X}^{3}$ with $P<0.0001$ and $\mathrm{r}^{2}=0.9815$. Based on regression analysis, the optimum growth of the isolates was estimated at $22^{\circ} \mathrm{C}$.

Molecular characterization. Based on the ITS sequences, two of the Penicillium isolates (F727 and F728) had 100\% sequence identity (KM249068), while the other two isolates (F730 and F732) had 99\% sequence identity (KM249070 and KM249072, respectively) with the first two isolates. Based on the BenA and RPB2 sequences, Penicillium isolates F727, F728, F730, and F732 had 100\% sequence identity (KM249108.1 and KM249117.1 for BenA and RPB2, respectively). Based on the ITS, the four sugar beet Penicillium isolates were placed into a clade closely related to $P$. freii and $P$. aurantiogriseum (Fig. 4). Based on BenA, the four sugar beet Penicillium isolates were placed into their own clade (Fig. 5). The most closely related species to this clade was $P$. aurantiogriseum. Based on RPB2, the four sugar beet Penicillium isolates were placed into their own clade (Fig. 6). The most closely related species to this clade was $P$. camemberti.

Rot tests. The data from both experiments were analyzed together because the experiments did not differ $(P=0.1199)$, interactions were not significant (expt*block $P=0.2835$, expt*strain $P=0.0615$, and block* strain $P=0.1265)$, and the variances were homogeneous $(P=$ $0.9399)$. There were significant differences $(P<0.0001)$ among the treatments for rot measured in millimeters: F732 $=25.0$ a; F727 $=$ $24.3 \mathrm{ab} ; \mathrm{F} 730=23.1 \mathrm{ab} ; \mathrm{F} 728=22.8 \mathrm{~b}$; and control $=0.8 \mathrm{c}$ [letters following the means represent separation based on Fisher's protected least significant difference (LSD) with $\alpha=0.05$; LSD $=2.1]$.

Isolations confirmed the presence of Penicillium in rot associated with the inoculated treatments and no Penicillium was found in the checks. The temperatures during the rot tests are documented in Figure 7. The storage building did not reach the set point until 30 November 2016, because night time ambient air was not cool enough to lower air temperature in the building to $1.1^{\circ} \mathrm{C}$ until this date.

\section{Discussion}

Historically, the most widely acknowledged sugar beet fungal rot pathogens in storage have been $B$. cinerea, $P$. betae, and $P$. vulpinum (Bugbee 1993; Fugate and Campbell 2009), while more recently an Athelia-like basidiomycete has also been described (Toda et al. 2012). On stored sugar beet roots, $P$. vulpinum has been shown to be the most prevalent Penicillium species in older literature, while other Penicillium species have also been documented to occur: $P$. cyclopium, P. duclauxii, P. expansum, P. funiculosum [now T. funiculosus], $P$. paneum, $P$. rubrum, $P$. stoloniferum, and $P$. variable [now $T$. variabilis] (Bugbee 1975, Bugbee and Nielsen 1978, Fugate and Campbell 2009, Liebe et al. 2016, Morotchkovsky 1936, Samson et al. 2011, Visagie et al. 2014). In a recent fungicide study (Strausbaugh et al. 2015) in a

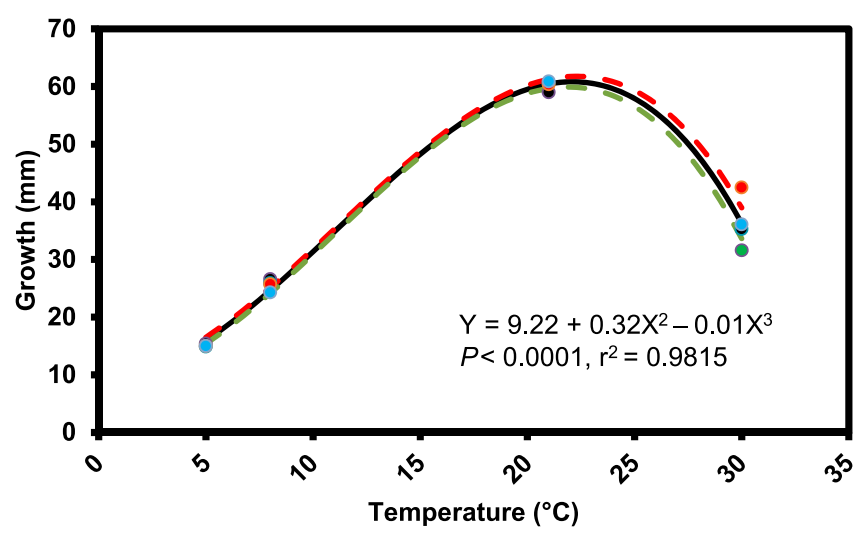

Fig. 3. Solid regression line for growth of four Penicillium cellarm sp. nov isolates from sugar beet roots after incubation for 12 days at $5,8,21$, and $30^{\circ} \mathrm{C}$ on Czapek yeast autolysate agar. Optimum hyphal growth was estimated to occur at $22^{\circ} \mathrm{C}$. Dashed lines represent the $95 \%$ confidence limits. 


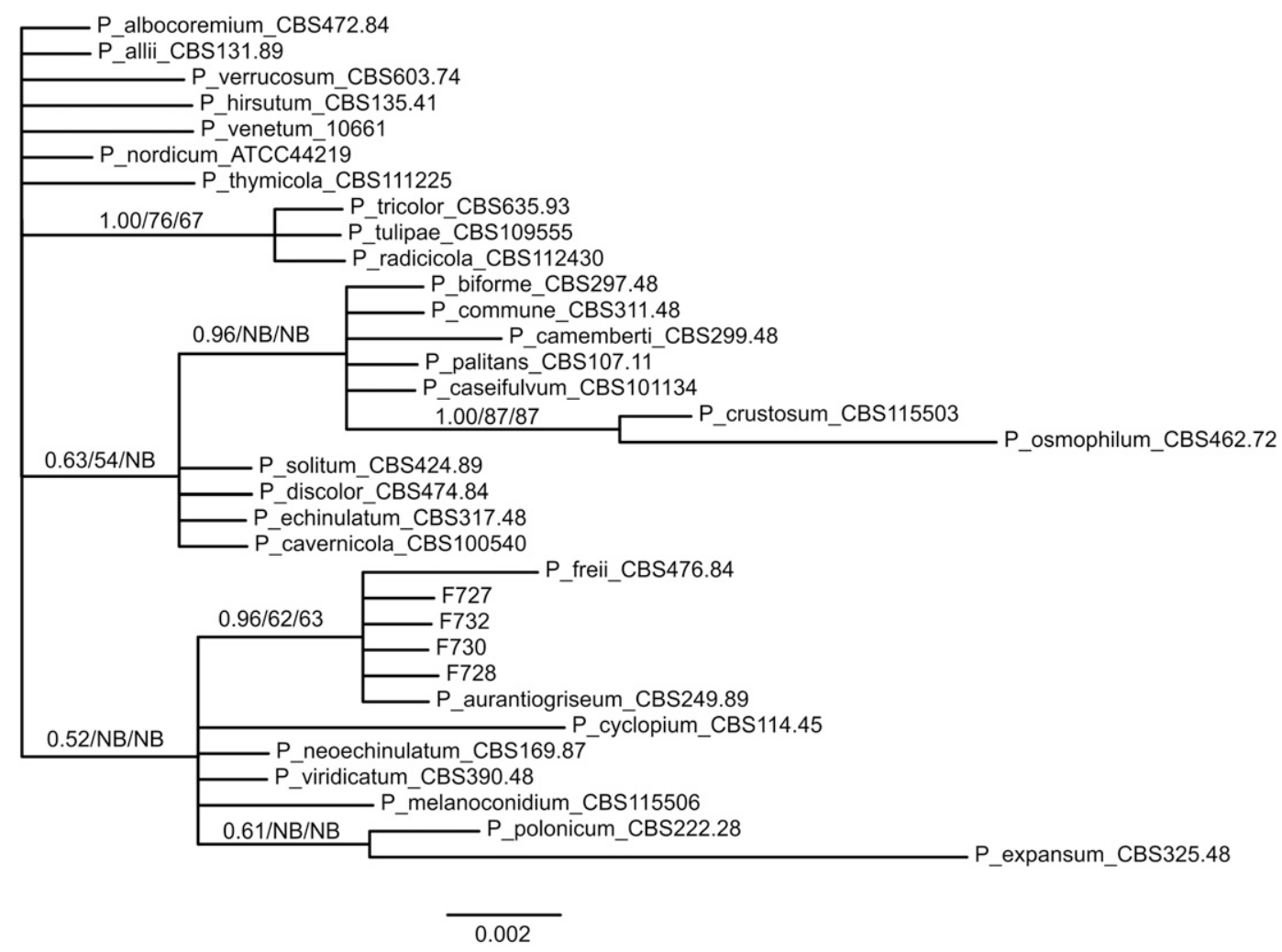

Fig. 4. Bayesian inference phylogenetic tree based on the ITS-5.8S DNA region, showing the relationships among Penicillium species type strains in the section Fasiculata and four isolates (F727, F728, F730, and F732) collected from sugar beet roots which represent a new Penicillium species. Penicillium expansum from section Penicillium was chosen as the outgroup. Numbers on nodes represent the statistical support for Bayesian method (posterior probabilities, left number), maximum likelihood (ML; 1,000 replicates, middle number), maximum parsimony (MP; 1,000 bootstrap replicates, right number), and NB = no branch. Penicillium species sequences were obtained from GenBank (Table 1) and the species names are followed by strain designations.

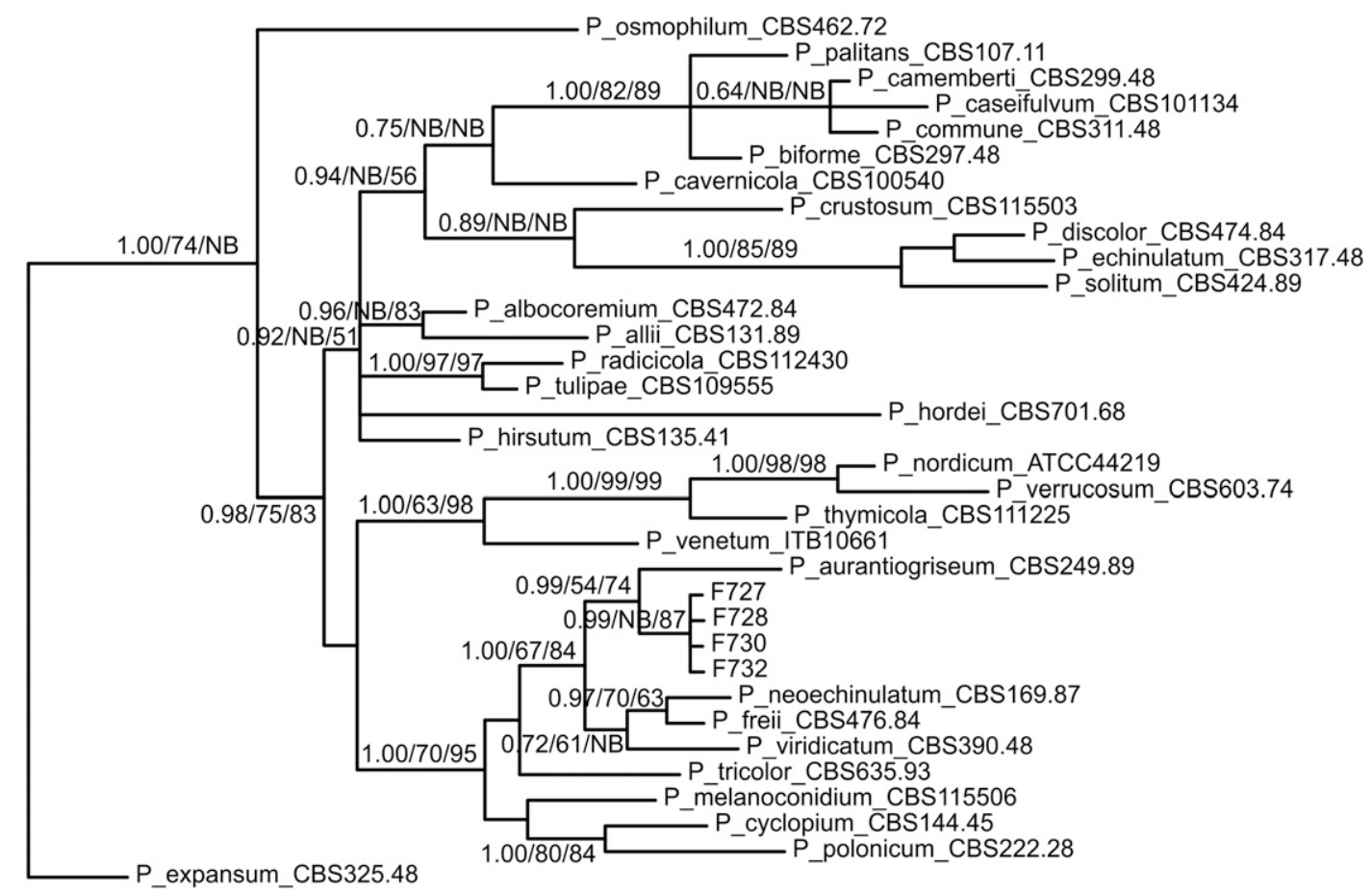

0.02

Fig. 5. Bayesian inference phylogenetic tree based on the $\beta$-tubulin (BenA) DNA region, showing the relationships among Penicillium species type strains in the section Fasiculata and four isolates (F727, F728, F730, and F732) collected from sugar beet roots which represent a new Penicillium species. Penicillium expansum from section Penicillium was chosen as the outgroup. Numbers on nodes represent the statistical support for Bayesian method (posterior probabilities, left number), maximum likelihood (ML; 1,000 replicates, middle number), maximum parsimony (MP; 1,000 bootstrap replicates, right number), and NB = no branch. Penicillium species sequences were obtained from GenBank (Table 1) and the species names are followed by strain designations. 
commercial Idaho storage building, a novel Penicillium species was documented to occur on sugar beet roots. In the current study, four of the sugar beet Penicillium isolates (F727, F728, F730, and F732) from this fungicide study were determined to represent a novel pathogenic species, Penicillium cellarum sp. nov., based on the methods for the polyphasic species concept recommended by Visagie et al. (2014).

Homogeneity of DNA sequences across the ITS, RPB2, and BenA regions indicates the four sugar beet Penicillium isolates represent a distinct clade. A few species such as $P$. aurantiogriseum, $P$. freii, and $P$. camemberti closely align with this distinct clade within a specific DNA region, but none of the currently recognized Penicillium species align with the distinct clade across all three DNA regions. These data strongly imply recognition as a species distinct from other Penicillium species. Of the three Penicillium species most closely aligned with the sugar beet isolates based on sequencing, $P$. camemberti has completely different colony morphology since it is white and floccose on CYA, MEA, and YES (Frisvad and Samson 2004). The sugar beet Penicillium isolates were dull blue-green on CYA, MEA, and YES compared with the darker blue green of P. aurantiogriseum and $P$. freii, but had a similar velutinous texture. On CYA, the sugar beet Penicillium isolates produced minute amounts of a colorless to pale tan exudate and orange reverse similar to $P$. aurantiogriseum, but differs from $P$. freii which produces copious amounts of exudate and has a cream to yellow reverse. On MEA, $P$. aurantiogriseum produces a red-brown diffusible pigment (Fig. 30b in Frisvad and Samson 2004), while the sugar beet isolates did not (Fig. 1b). The sugar beet isolates were terverticillate with globose conidia, rough-walled stipes and rami (those of $P$. aurantiogriseum are smooth to finely roughened), and psychrotolerant, which means the isolates associated with this new species fit well with other species in the section Fasciculata, but differ from closely related species in some respects. Statistical analysis of micromorphological characters in the four sugar beet Penicillium isolates revealed no differences among the four with regard to conidiogenous cells (phialides) and conidia. However, the length of

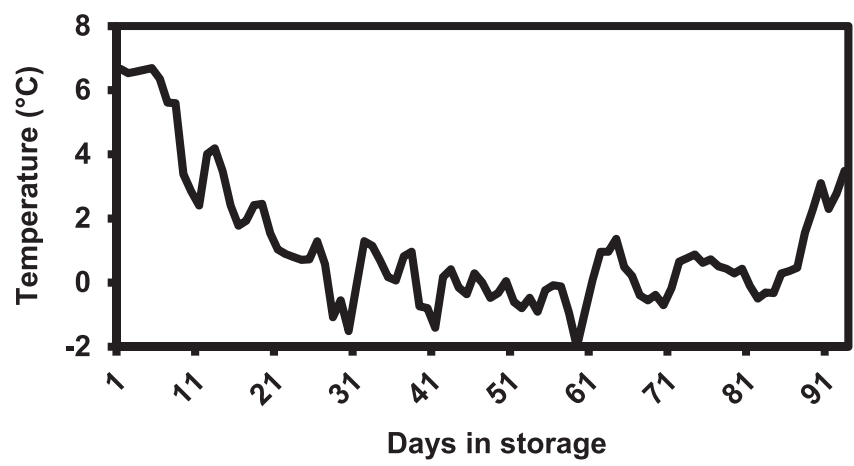

Fig. 7. Average daily temperature $\left({ }^{\circ} \mathrm{C}\right)$ in a commercial sugar beet pile from 9 November 2016 to 9 February 2017 in an indoor storage facility in Paul, ID.

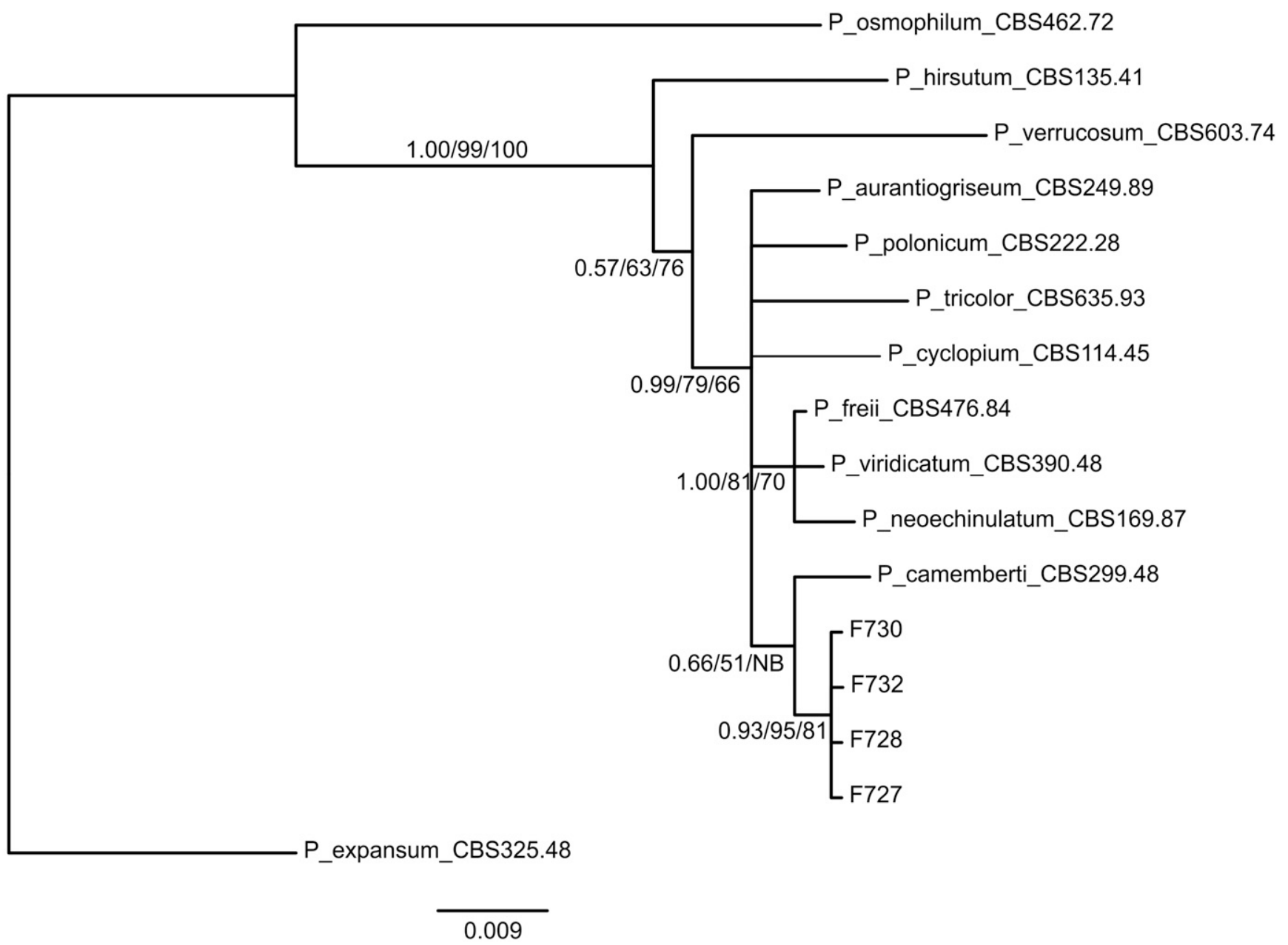

Fig. 6. Bayesian inference phylogenetic tree based on the RNA polymerase II second largest subunit (RPB2) region, showing the relationships among Penicillium species type strains in the section Fasiculata and four isolates (F727, F728, F730, and F732) collected from sugar beet roots which represent a new Penicillium species. Penicillium expansum from section Penicillium was chosen as the outgroup. Numbers on nodes represent the statistical support for Bayesian method (posterior probabilities, left number), maximum likelihood (ML; 1,000 replicates, middle number), maximum parsimony (MP; 1,000 bootstrap replicates, right number), and. NB = no branch. Penicillium species sequences were obtained from GenBank (Table 1) and the species names are followed by strain designations. 
metulae and width of rami were found to differ, although the actual degree of difference was not large. Such slight differences are unsurprising, given that with the inherent variability in this genus, only 70 to $80 \%$ of isolates are readily identifiable on a morphological basis (Pitt 2000).

Penicillium species involved in storage rot have frequently been associated with wounds and are prevalent, but not necessarily the most damaging pathogen present (Bugbee 1975, 1982, 1993; Bugbee and Nielsen 1978, Fugate and Campbell 2009; Liebe et al. 2016; Mumford and Wyse 1976). In the 1970s in the Red River Valley, $P$. vulpinum and Phoma betae were isolated more than $70 \%$ of the time, but $P$. betae was considered the more damaging pathogen because it decayed roots at a faster rate (Bugbee 1982). A fungicide storage study from the 1970s targeted at the Pacific Northwest focused on P. vulpinum and B. cinerea indicating Penicillium was important in that region as well (Mumford and Wyse 1976). In Europe, Penicillium was recently acknowledged as being one the dominant fungal species in storage (Liebe et al. 2016, Liebe and Varrelmann 2014).

Environmental conditions such as temperature can also influence the presence of Penicillium on sugar beet roots. When roots were stored at $20^{\circ} \mathrm{C}, P$. paneum was one of the dominant fungal species present (Liebe et al. 2016). During a recent fungicide study conducted in an indoor commercial storage building in Idaho (Strausbaugh et al. 2015), one of the dominant Penicillium species discovered was the novel species described here as $P$. cellarum. The set point for the commercial storage building was $1.1^{\circ} \mathrm{C}$. Because the storage is cooled with ambient air, if night time temperatures are not cool enough to hit set point, then the temperatures in the storage will begin to rise. The storage began being filled in early October, but in 2016 ambient temperatures were not cool enough to reach set point until 30 November. Over this temperature range, the $P$. cellarum has been shown to rot sugar beet root tissue in the rot tests. Finding $P$. cellarum active over a wide temperature range is not surprising, because in temperature growth studies $P$. cellarum has been documented to grow over a considerable temperature range (Fig. 3). However, the optimum temperature has been estimated to be $22^{\circ} \mathrm{C}$, indicating it will likely be favored by higher storage temperatures.

Four Penicillium isolates collected as part of a storage study (Strausbaugh et al. 2015) with sugar beet roots on top of an indoor commercial pile were determined to represent a novel pathogenic species, Penicillium cellarum sp. nov. These isolates were determined to have the ability to cause sugar beet root rot in storage, but future studies which compare them with other fungal pathogens and determine their incidence are needed to establish the importance of this novel Penicillium species.

\section{Acknowledgments}

These data support the objectives of the United States Department of Agriculture CRIS project 5368-21220-003-00D. We acknowledge the Amalgamated Sugar Co., LLC; Amalgamated Research, LLC; Beet Sugar Development Foundation; and Snake River sugar beet growers for supporting our research. We also gratefully acknowledge the technical support of Josh Reed, Jim Foerster, and Shari Lupien.

\section{Literature Cited}

Altschul, S. F., Madden, T. L., Schäffer, A. A., Zhang, J., Zhang, Z., Miller, W., and Lipman, D. J. 1997. Gapped BLAST and PSI-BLAST: A new generation of protein database search programs. Nucleic Acids Res. 25:3389-3402.

Boysen, M. E., Jacobsson, K.-G., and Schnürer, J. 2000. Molecular identification of species from the Penicillium roqueforti group associated with spoiled animal feed. Appl. Environ. Microbiol. 66:1523-1526.

Bugbee, W. M. 1975. Penicillium claviformae and Penicillium variabile: Pathogens of stored sugar beets. Phytopathology 65:926-927.

Bugbee, W. M. 1976. Penicillium claviformae: Sugar beet pathogen and antagonist of Botrytis cinerea. Can. J. Plant Sci. 56:647-649.

Bugbee, W. M. 1982. Storage rot of sugar beet. Plant Dis. 66:871-873.

Bugbee, W. M. 1993. Storage. Pages 551-570 in: The Sugar Beet Crop: Science into Practice. D. A. Cooke and R. K. Scott, eds. Chapman and Hall, London.
Bugbee, W. M., and Cole, D. F. 1976. Sugarbeet storage rot in the Red River Valley 1974-75. J. Am. Soc. Sugar Beet Technol. 19:19-24.

Bugbee, W. M., and Nielsen, G. E. 1978. Penicillium cyclopium and Penicillium funiculosum as sugarbeet storage rot pathogens. Plant Dis. Rptr. 62:953-954.

Campbell, L. G., and Bugbee, W. M. 1993. Pre-breeding for root-rot resistance. J. Sugar Beet Res. 30:241-251.

Frisvad, J. C., and Samson, R. A. 2004. Polyphasic taxonomy of Penicillium subgenus Penicillium. A guide to identification of food and air-borne terverticillate Penicillia and their mycotoxins. Stud. Mycol. 49:1-173.

Fugate, K., and Campbell, L. 2009. Postharvest deterioration of sugar beet. Pages 92-94 in: Compendium of Beet Diseases and Pests, 2nd Ed., R. M. Harveson, L. E. Hanson, and G. Hein, eds. American Phytopathological Society, St. Paul, MN.

Hall, T. 1999. BioEdit: A user-friendly biological science sequence alignment editor and analysis program for Windows 95/98/NT. Nucl. Acids Symp. Ser. 41:95-98.

Huff, J. 2013. The hidden cost of beet storage. Sugarbeet (2013 Harvest Issue):3-4 Amalgamated Sugar Company, LLC, Boise, ID.

Larkin, M. A., Blackshields, G., Brown, N. P., Chenna, R., McGettigan, P. A., McWilliam, H., Valentin, F., Wallace, I. M., Wilm, A., Lopez, R., Thompson, J. D., Gibson, T. J., and Higgins, D. G. 2007. Clustal W and Clustal X version 2.0. Bioinformatics 23:2947-2948.

Liebe, S., and Varrelmann, M. 2014. Impact of root rot pathogens on storage of sugar beets and control measures. Zuckerindustrie 139:443-452.

Liebe, S., Wibberg, D., Winkler, A., Pühler, A., Schlüter, A., and Varrelmann, M. 2016. Taxonomic analysis of the microbial community in stored sugar beets using high-throughput sequencing of different marker genes. FEMS Microbiol. Ecol. 92:1-12.

Miles, W. G., Shaker, F. M., Nielson, A. K., and Ames, R. R. 1977. A laboratory study on the ability of fungicides to control beet rotting fungi. J. Am. Soc. Sugar Beet Technol. 19:288-293.

Morotchkovsky, S. F. 1936. Fungi of the genus Penicillium in sugar beets. (In Russian). Bull. de Sci. Recueil Biol. Univ. Kiev 2:57-86.

Mumford, D. L., and Wyse, R. E. 1976. Effect of fungus infection on respiration and reducing sugar accumulation of sugarbeet roots and use of fungicides to reduce infection. J. Am. Soc. Sugar Beet Technol. 19:157-162.

Nihlgård, M., Levall, M., Jonsson, R., Lennefors, B.-L., Larson, R., and Steinrucken, G. 2009. Storage diseases - assessment and implications for breeding. J. Sugar Beet Res. 46:91.

Peterson, C. L., Hall, M. C., and Traveller, D. J. 1984. Sugarbeet storage experiments. Pap. No.84-4040. Am. Soc. Agric. Eng., Knoxville, TN.

Pitt, J. I. 2000. A Laboratory Guide to Common Penicillium Species, 3rd Ed. Food Sci. Australia, North Ryde, Australia.

Ronquist, F., and Huelsenbeck, J. P. 2003. MrBayes 3: Bayesian phylogenetic inference under mixed models. Bioinformatics 19:1572-1574

Samson, R. A., Yilmaz, N., Houbraken, J., Spierenburg, H., Seifert, K. A., Peterson, S. W., Varga, J., and Frisvad, J. C. 2011. Phylogeny and nomenclature of the genus Talaromyces and taxa accommodated in Penicillium subgenus Biverticillium. Stud. Mycol. 70:159-183.

Strausbaugh, C. A., Eujayl, I. A., Rearick, E., Foote, P., and Elison, D. 2009. Sugar beet cultivar evaluation for storability and rhizomania resistance. Plant Dis. 93: 632-638.

Strausbaugh, C. A., Neher, O., Rearick, E., and Eujayl, I. A. 2015. Influence of harvest timing, fungicides, and Beet necrotic yellow vein virus on sugar beet storage. Plant Dis. 99:1296-1309.

Strausbaugh, C. A., Rearick, E., Camp, S., Gallian, J. J., and Dyer, A. T. 2008. Influence of Beet necrotic yellow vein virus on sugar beet storability. Plant Dis. 92:581-587

Strausbaugh, C. A., Rearick, E., Eujayl, I. A., and Foote, P. 2011. Influence of Rhizoctonia-bacterial root rot complex on storability of sugarbeet. J. Sugar Beet Res. 48:155-180.

Tamura, K., Peterson, D., Peterson, N., Stecher, G., Nei, M., and Kumar, S. 2011. MEGA5: Molecular evolutionary genetics analysis using maximum likelihood evolutionary distance, and maximum parsimony methods. Mol. Biol. Evol. 28: 2731-2739.

Toda, T., Strausbaugh, C. A., Rodriquez-Carres, M., and Cubeta, M. 2012 Characterization of a Basidiomycete fungus from stored sugar beet roots. Mycologia 104:70-78.

Visagie, C. M., Houbraken, J., Frisvad, J. C., Hong, S.-B., Klaassen, C. H. W., Perrone, G., Seifert, K. A., Varga, J., Yaguchi, T., and Samson, R. A. 2014 Identification and nomenclature of the genus Penicillium. Stud. Mycol. 78: 343-371.

Wyse, R. E. 1978. Effect of low and fluctuating temperatures on storage life of sugarbeets. J. Am. Soc. Sugar Beet Technol. 20:33-42.

Wyse, R. E., and Peterson, C. L. 1979. Effect of injury on respiration rates of sugarbeet roots. J. Am. Soc. Sugar Beet Technol. 20:269-280. 